\title{
Protein 1 (Clara cell protein) serum levels in lung cancer patients receiving chemotherapy
}

\author{
H. Nomori*, H. Horio*, R. Kobayashi**, S. Morinaga ${ }^{+}$, Y. Hirabayashi++
}

Protein 1 (Clara cell protein) serum levels in lung cancer patients receiving chemotherapy. H. Nomori, H. Horio, R. Kobayashi, S. Morinaga, Y. Hirabayashi. @ERS Journals Ltd 1995.

ABSTRACT: As many antineoplastic drugs can cause injury to alveolar pneumocytes, Clara cells (nonciliated, nonmucous epithelial cells of the bronchioles) may also be damaged by such drugs. Protein 1 (P1) is an $\alpha$-microprotein secreted by Clara cells. The effect of antineoplastic drugs on Clara cells is examined by the measurement of serum levels of $P 1$ in patients with lung cancer receiving chemotherapy.

Serum levels of $\mathbf{P 1}$ were studied in 36 patients with lung cancer, before chemotherapy and 5-7, 10-12 and 14-18 days after chemotherapy. One hundred and eight healthy subjects, matched by sex and age, acted as controls.

There was no significant difference in P1 serum levels between patients with lung cancer and healthy controls. P1 serum levels decreased significantly 5-7 and 10-12 days after chemotherapy, recovering thereafter.

We conclude that P1 serum levels do not differ between lung cancer patients and healthy controls, and that antineoplastic drugs inhibit the synthesis or secretion of P1 by Clara cells in the early period after the administration of medication.

Eur Respir J., 1995, 8, 1654-1657.
Depts of *Surgery, ${ }^{* *}$ Medicine, +Pathology, and +Laboratory Medicine, Saiseikai Central Hospital, Minato-ku, Tokyo, Japan. ${ }^{++}$Clinical Chemistry Division, Immunological Chemistry, SRL, Inc.

Correspondence: H. Nomor Dept of Surgery

Saiseikai Central Hospital 1-4-17 Mita

Minato-ku

Tokyo 108

Japan.

Keywords: Anticancer drugs

Clara cells

interstitial pneumonia

lung cancer

protein 1

pulmonary toxicity

Received: February 141995

Accepted after revision June 251995
Clara cells are nonciliated nonmucous epithelial cells of the bronchioles, having the morphological characteristics of secretory cells [1]. Although the role of Clara cells remains to be clarified, it is thought to be important in the carcinogenesis of lung cancer [2, 3], in surfactant production in terminal airways [4-6], and in the regulation of the inflammatory response in the lungs [7, 8]. However, the relationship of Clara cells to different pathological conditions of the lung remains to be studied adequately.

Protein 1 (P1), an $\alpha$-microprotein with a molecular weight of $10 \mathrm{kDa}$, was initially found in the urine of patients with renal tubular dysfunction [9-11]. In 1992, BERNARD and co-workers [12] demonstrated that P1 was identical to the Clara cell $10 \mathrm{kDa}$ protein $(\mathrm{CC} 10)$, which was originally reported as a Clara cell secretory protein by SINGH et al. [13]. Using in situ hybridization, BROERS et al. [14] demonstrated that the $\mathrm{CC} 10$ gene was also expressed in nonciliated columnar epithelial cells in the large and small bronchi, as well as those in the bronchioles (Clara cells). We demonstrated, by immunohistochemical study of all types of tissue, that P1 and CC10 were most significantly distributed in Clara cells [15].

It has been reported that many antineoplastic drugs can cause injury of alveolar pneumocytes, which results in abnormal surfactant production and/or composition
[16-19], and, in some patients, progresses to clinically manifested interstitial pneumonia. Although Clara cells are bronchiolar epithelial cells, they have close embryological and functional relationship with alveolar pneumocytes $[4,6,20]$. In order to examine the effect of antineoplastic drugs on Clara cells, we studied P1 serum levels in 36 patients with lung cancer who had received systemic chemotherapy. In addition, in order to evaluate the P1 serum levels in the patients with lung cancer, the prechemotherapy P1 values were compared to the P1 values in 108 healthy controls matched by sex and age.

Subjects and methods

\section{Cases}

We studied 36 consecutive patients with lung cancer (27 males and 9 females, aged 48-72 (mean 62) yrs) who underwent systemic chemotherapy between June 1993 and August 1994 at Saiseikai Central Hospital, Tokyo, Japan. Twenty four $(67 \%)$ of the patients were smokers, and the remaining 12 patients were nonsmokers or ex-smokers. Histological types were adenocarcinoma (22), squamous cell carcinoma (5), large cell 
carcinoma (4), and small cell carcinoma (5). Chemotherapy was administered as the first course in 22 , the second in 11 , and the third in 3 cases. The period from prior chemotherapy exceeded 28 days in all patients. No patients had prior thoracic radiation therapy or lung resection, nor had any suffered from clinically manifested pulmonary complications caused by antineoplastic drugs.

All drugs were administered in the full dose, i.e. cisplatin (cis dichloro diaminoplatinum; CDDP) $80 \mathrm{mg} \cdot \mathrm{m}^{-2}$ body mass intravenously (i.v.) on Day 1; carboplatin (CBDCA) $300 \mathrm{mg} \cdot \mathrm{m}^{-2}$ i.v. on Day 1 ; vindesine (VDS) $3 \mathrm{mg} \cdot \mathrm{m}^{-2}$ i.v. on Day 1; and etoposide (VP-16) $100 \mathrm{mg} \cdot \mathrm{m}^{-2}$ i.v. on Days 1, 3 and 5. Of 31 cases with non-small cell carcinoma, 24 cases were treated using a combination of CBDCA and VDS, and 7 cases with CDDP and VDS. The five cases with small cell carcinoma were treated with a combination of CDDP and VP-16. No patients suffered pulmonary complications or renal toxicity due to antineoplastic drugs. Mean \pm SD values of serum blood urea nitrogen (BUN) were $14.1 \pm 4.2 \mathrm{mg} \cdot \mathrm{dL}^{-1}$ before chemotherapy, $15.2 \pm 3.8 \mathrm{mg} \cdot \mathrm{dL}^{-1}$ at $5-7,14.6 \pm 3.9 \mathrm{mg} \cdot \mathrm{dL}^{-1}$ at $10-12$, and $16.1 \pm .8 \mathrm{mg} \cdot \mathrm{dL}^{-1}$ at $14-18$ days after chemotherapy. Mean \pm SD values of serum creatinine were $0.9 \pm 0.3 \mathrm{mg} \cdot \mathrm{dL}^{-1}$ before chemotherapy, $1.0 \pm 0.4 \mathrm{mg} \cdot \mathrm{dL}^{-1}$ at $5-7,0.9 \pm 0.4 \mathrm{mg} \cdot \mathrm{dL}^{-1}$ at $10-12$, and $1.0 \pm 0.4 \mathrm{mg} \cdot \mathrm{dL}^{-1}$ at 14-18 days after chemotherapy.

Prechemotherapy P1 serum levels were measured within one week before chemotherapy. Postchemotherapy P1 serum levels were measured three times, at 5-7, 10-12, and 14-18 days after the first date of medication.

\section{Controls}

As a control for each prechemotherapy P1 serum level in the patients with malignancies, we selected three healthy subjects (total 108 cases) who underwent routine medical examination. Possible control subjects were excluded if they had any evidence of lung, heart, liver, or kidney disease, or a history of major surgery. Control cases were matched with the individual patients for sex and age $( \pm 5$ yrs). Sixty two cases $(57 \%)$ of the control subjects were smokers, and the remaining 46 cases were nonsmokers or ex-smokers.

\section{Storage of samples}

Serum samples were obtained in the morning before eating. When the serum samples had been examined for their original purposes, all of the remaining samples were stored at $-80^{\circ} \mathrm{C}$ until the analysis of $\mathrm{P} 1$ levels.

\section{Immunoglobulin coating of latex particles}

One tenth of a millilitre of purified anti-rabbit immunoglobin $\mathrm{G}(\mathrm{IgG})$ against P1 (Dakopatts Ltd) in $0.2 \mathrm{~mL}$ of $0.1 \mathrm{~mol}$ phosphate buffered sodium (PBS), and $0.2 \mathrm{~mL}$ of a $10 \%$ suspension of polystyrene latex particles $(0.80$ $\mu \mathrm{m}$ in diameter, Baxter Ltd) were mixed well using a vortex mixer, incubated for $1 \mathrm{~h}$ at room temperature, and then centrifuged at $3,000 \times \mathrm{g}$ for $10 \mathrm{~min}$. After washing in $4 \mathrm{~mL}$ of $0.1 \mathrm{~mol}$ PBS (pH 5.0), the coated particles were resuspended in $4 \mathrm{~mL}$ of $0.1 \mathrm{~mol}$ PBS containing $0.1 \%$ sodium azide whose final concentration was $0.25 \%$ $(\mathrm{w} / \mathrm{v})$. Particles were stored at $4^{\circ} \mathrm{C}$.

\section{Procedures}

The P1 assay was performed using a fully automated system, i.e. a Behring Nephelometer Analyser (Behringwerke AG). One hundred microlitres of serum diluted 10 times with dilution buffer (Behringwerke AG), $30 \mu \mathrm{L}$ of antiserum-coated latex particles, and $160 \mu \mathrm{L}$ of reaction buffer (Behringwerke AG) were pipetted into a reaction cuvet and preincubated at room temperature for 6 s. The increase in light scattering energy after the mixing of the sample was measured at two defined times (6 and $726 \mathrm{~s})$. The second signal measured was then subtracted from the first, and the intrinsic light scattering energy of the samples, the coating particles, and the cuvet was eliminated. Accurate sample concentrations of P1 can be determined from the standards plotted on a standard curve. The P1 assay was calibrated with purified P1 (Dakopatts). The analytical range was 3.75-3,000 $\mu \mathrm{g} \cdot \mathrm{L}^{-1}$.

\section{P1 recovery test}

From 20 to $200 \mu \mathrm{g} \cdot \mathrm{L}^{-1}$ of the P1 standard (Dakopatts Ltd) were added to serum samples, and aliquots of the recovered P1 were assayed.

\section{Statistics}

Conditional logistic analysis was used to determine the difference in P1 serum levels between the patients with lung cancer and their corresponding healthy controls. The differences of the paired P1 values in each patient before and after chemotherapy were analysed for significance by the two-tailed Student's t-test of paired values. Values of $p$ less than 0.05 were accepted as significant. The relationship between the prechemotherapy and postchemotherapy P1 serum levels was analysed for significance by a two-tailed Student's t-test.

\section{Results}

The result of the $\mathrm{P} 1$ recovery test showed that the average recovery was $106 \pm 6 \%$, which indicated the P1 measurement method was reliable and specific for P1 values. The storage of samples at $-80^{\circ} \mathrm{C}$ for 1 month did not change the P1 values.

The distributions of prechemotherapy P1 serum levels in the patients and the P1 serum levels in healthy subjects are given in figure 1. P1 serum levels both in the patients and healthy subjects were widely distributed: 


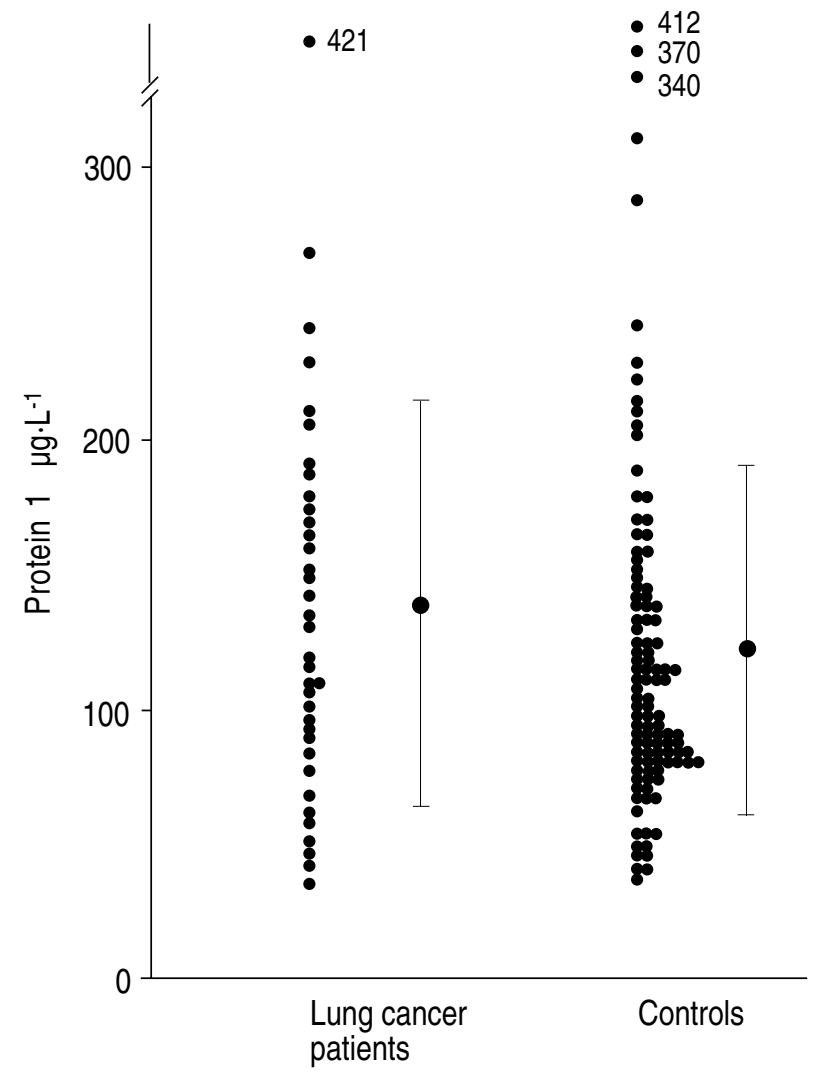

Fig. 1. - Protein 1 serum levels in patients with lung cancer and in corresponding controls. Bars represent mean \pm sD.

from $38-421 \mu \mathrm{g} \cdot \mathrm{L}^{-1}$ in the patients with lung cancer, and from $40-412 \mu \mathrm{g} \cdot \mathrm{L}^{-1}$ in the healthy subjects. Mean and SD values of the P1 serum levels were $140 \pm 76$ and $122 \pm 66 \mu \mathrm{g} \cdot \mathrm{L}^{-1}$ in patients with lung cancer and in the healthy subjects, respectively. Thus, there was no significant difference between them. The percentage of smokers was not significantly different between the lung cancer patients and controls.

Mean and SD values for postchemotherapy P1 serum levels in all cases were $114 \pm 62 \mu \mathrm{g} \cdot \mathrm{L}^{-1}$ at 5-7 days, $131 \pm 62$ $\mu \mathrm{g} \cdot \mathrm{L}^{-1}$ at $10-12$ days, and $138 \pm 71 \mu \mathrm{g} \cdot \mathrm{L}^{-1}$ at $14-18$ days after chemotherapy (fig. 2). P1 serum levels 5-7 and 10-12 days after chemotherapy were significantly lower

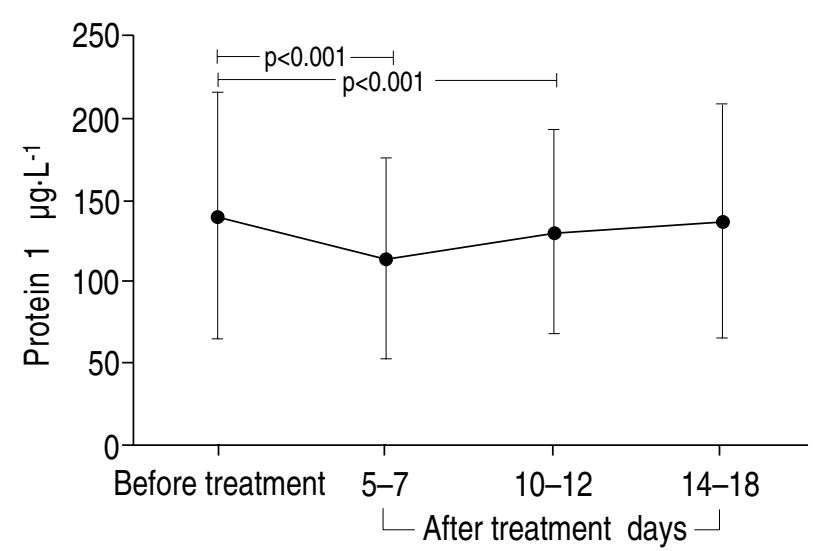

Fig. 2. - Changes in protein 1 serum levels before and after chemotherapy. Bars represent mean \pm SD.
Table 1. - Correlation between prechemotherapy and postchemotherapy protein 1 (P1) serum levels

\begin{tabular}{cccc}
\hline $\begin{array}{c}\text { Post chemotherapy } \\
\text { days }\end{array}$ & $\begin{array}{c}\text { Cases } \\
\mathrm{n}\end{array}$ & $\begin{array}{c}\text { Coefficient of } \\
\text { correlation with P1 }\end{array}$ & p-values \\
\hline $5-7$ & 36 & 0.980 & $<0.001$ \\
$10-12$ & 36 & 0.987 & $<0.001$ \\
$14-18$ & 36 & 0.991 & $<0.001$ \\
\hline
\end{tabular}

Table 2. - Combination chemotherapy and changes in protein $1(\mathrm{P} 1)$ serum levels before and after treatment

\begin{tabular}{|c|c|c|c|c|c|}
\hline \multirow{3}{*}{ Combination } & \multirow{3}{*}{$\begin{array}{c}\text { Cases } \\
\mathrm{n}\end{array}$} & \multicolumn{4}{|c|}{ P1 serum levels $\mu \mathrm{g} \cdot \mathrm{L}^{-1}$} \\
\hline & & \multirow{2}{*}{$\begin{array}{l}\text { Before } \\
\text { treatment }\end{array}$} & \multicolumn{3}{|c|}{ Post treatment (days) } \\
\hline & & & $5-7$ & $10-12$ & 14-18 \\
\hline $\mathrm{CBDCA}+$ & 24 & $133 \pm 87$ & $107 \pm 70 * * *$ & $126 \pm 81 * *$ & $131 \pm 82$ \\
\hline CDDP+VDS & 7 & $155 \pm 39$ & $129 \pm 32 * *$ & $144 \pm 29$ & $157 \pm 28$ \\
\hline $\mathrm{CDDP}+\mathrm{VP}-16$ & 5 & $153 \pm 57$ & $101 \pm 48 *$ & $127 \pm 41$ & $129 \pm 43$ \\
\hline
\end{tabular}

Values are presented as mean \pm SD. CBDCA: carboplatin; VDS: vindesine; CDDP: cisplatin; VP-16: etoposide. ***: $\mathrm{p}<0.001$; $* *: p<0.01 ; *: p<0.05$ ( $p$-values in the difference of P1 serum levels before and after treatment).

than their paired values before chemotherapy $(\mathrm{p}<0.001)$, and recovered 14-18 days after treatment. P1 serum levels at 5-7, 10-12, and 14-18 days after chemotherapy showed a significant positive correlation with those of the prechemotherapy values $(\mathrm{p}<0.001)$ (table 1$)$.

All types of combination chemotherapy also showed a decrease in P1 serum levels 5-8 and 10-12 days after the administration of medication (table 2). The 24 patients who received the combination of CBDCA and VDS showed a significant decrease of P1 serum levels 5-7 and 10-12 days after treatment $(\mathrm{p}<0.001$ and $\mathrm{p}<0.01)$. The seven patients treated with CDDP and VDS, and five patients treated with CDDP and VP-16 showed a significant decrease of the values 5-7 days after treatment $(\mathrm{p}<0.01$ and $\mathrm{p}<0.05$, respectively).

\section{Discussion}

A large number of Clara cells are present in the bronchioles of normal human lungs. P1 secreted into the airways from Clara cells is absorbed into the blood through the bronchial epithelium [15, 21]. BERNARD and co-workers [21] demonstrated that P1 values in bronchoalveolar lavage (BAL) correlated significantly with those in serum, and that P1 values in serum could be an indicator of the total amount of protein synthesized by Clara cells. P1 values in serum would also be more reliable than those in BAL, since the latter are affected by variable dilutions of the sample.

BERNARD and co-workers [21] reported that P1 values in BAL and serum were significantly lower in eight patients with lung cancer than in 25 healthy subjects. However, the present study, using controls matched by sex and age, demonstrated that P1 serum levels were not affected by the association with lung cancer. 
It has been reported that many antineoplastic drugs can cause chemically induced and/or immune-mediated pneumonitis, resulting in necrosis of type I pneumocytes, abnormal proliferation of type II pneumocytes, changes in pulmonary surfactant composition, and, in some patients, progressive advance to clinically manifested interstitial pneumonia [16-19]. The present study showed that the P1 serum levels had decreased significantly 5-7 and 10-12 days after chemotherapy, and had recovered almost to the prechemotherapy levels 14-18 days after chemotherapy. Although the antineoplastic drugs used in the present study are not known to affect the lung clinically, these drugs might cause subclinical damage of bronchiolar epithelium, such as the inhibition of P1 synthesis or secretion from Clara cells.

Several reports have suggested that Clara cell protein could have anti-inflammatory activity, i.e. inhibition of phospholipase A2 [7] and production and biological activity of interferon- $\gamma$ [8]. Therefore, we assume that P1 secreted from Clara cells, through its anti-inflammatory activity, may play an important role in recovery from subclinical drug-induced lung damage.

Our data have demonstrated that the P1 serum levels were widely distributed both in lung cancer patients and healthy subjects. Although we cannot state the minimum P1 serum levels for normal function of Clara cells, it can be stated that the monitoring of postchemotherapy $\mathrm{P} 1$ values in each patient could provide important information on the recovery from lung damage due to chemotherapy.

In conclusion, we found that $\mathrm{P} 1$ serum levels decreased after chemotherapy. The functions and metabolism of $\mathrm{P} 1$ remain to be elucidated, however, and its physical and biological properties and its role in relation to lung disease in vivo require much more study.

Acknowledgements: The authors thank H. Furukawa for the collection of serum samples.

\section{References}

1. Kuhn C, Callaway LA, Askin FB. The formation of granules in the bronchiolar Clara cells of the rat. $J$ Ultrastruct Res 1974; 49: 387-400.

2. Nakanishi K, Kawai T, Suzuki M. Large intracytoplasmic body in lung cancer compared with Clara cell granule. Am J Clin Pathol 1987; 88: 472-477.

3. Ogata T, Endo K. Clara cell granules of peripheral lung cancers. Cancer 1984; 54; 1635-1644.

4. Niden AH. Bronchiolar and large alveolar cells in pulmonary phospholipid metabolism. Science 1967; 158: 1323-1324.

5. Auten RL, Watkins RH, Shapiro DL, Horowitz S. Surfactant apoprotein A (SP-A) is synthesized in airway cells. Am J Respir Cell Mol Biol 1990; 3: 491-496.
6. Sugahara K, Iyama K, Sano K, Morioka T. Overexpression of pulmonary surfactant apoprotein A mRNA in alveolar type II cells and nonciliated bronchiolar (Clara) epithelial cells in streptozotocin-induced diabetic rats demonstrated by in situ hybridization. Am J Respir Mol Biol 1992; 5: 307-314.

7. Singh G, Katyal SL, Brown WE, Kennedy AL, Singh $\mathrm{U}$, Wong-Chong M. Clara cell $10 \mathrm{kDa}$ protein $(\mathrm{CC} 10)$ : comparison of structure and function to uteroglobin. Biochem Biophys Acta 1990; 1039: 348-355.

8. Dierynck I, Bernard A, Roels H, De Ley M. Potent inhibition of both human interferon- $\gamma$ production and biologic activity by the Clara cell protein CC16. Am J Respir Cell Mol Biol 1995; 12: 205-210.

9. Bernard A, Lauwerys R, Noel A, Vandeleene B, Lambert A. Urine protein 1: a sex-dependent marker of tubular or glomerular dysfunction. Clin Chem 1989; 35: 21412142.

10. Bernard A, Lauwerys R, Noel A, Vandeleene B, Lambert A. Determination by latex immunoassay of protein 1 and pathological urine. Clinica Chem Acta 1991; 210: 231246.

11. Jackson PJ, Turner R, Keen JN, Brooksbank RA, Cooper EH. Purification and partial amino acid sequence of human urine protein 1. J Chromatogr 1988; 452: 359367.

12. Bernard A, Roels H, Lauwerys R, et al. Protein 1 is a secretory protein of the respiratory and urogenital tracts identical to the Clara cell protein. Clin Chem 1992; 38: 434-435.

13. Singh G, Katyal SL, Ward JM, Gottron SA, Wong-Chong ML, Riley EJ. Secretory proteins of the lung in rodents: immunocytochemistry. J Histochem Cytochem 1985; 33: 564-568.

14. Broers JLV, Jensen SM, Travis WD, et al. Expression of surfactant-associated protein-A and Clara cell 10 kilodalton mRNA in neoplastic and non-neoplastic human lung tissue as detected by in situ hybridization. Lab Invest 1992; 66: 337-346.

15. Nomori H, Morinaga S, Kobayashi R, Torikata C. Protein 1 and Clara cell $10 \mathrm{kDa}$ protein distribution in normal and neoplastic tissues with emphasis on the respiratory tract. Virchows Archiv (A) 1994; 424: 517-523.

16. Rossi GA, Balbi B, Benatti U, et al. Changes in pulmonary surfactant composition following MACC chemotherapy for lung carcinoma. Eur J Respir Dis 1987; 71: 400-409.

17. Rosenow III EC. The spectrum of drug-induced pulmonary disease. Ann Intern Med 1972; 77: 977-991.

18. Sostman HD, Matthay RA, Putman CE. Cytotoxic druginduced lung disease. Am J Med 1977; 62: 608-615.

19. Weiss RB, Muggia FM. Cytotoxic drug-induced pulmonary disease: update 1980. Am J Med 1980: 68: 259-266.

20. Auten RL, Watkins RH, Shapiro DL, Horowitz S. Surfactant apoprotein A (SP-A) is synthesized in airway cells. Am J Respir Cell Mol Biol 1990; 3: 491-496.

21. Bernard A, Marchandise FX, Depeichin S, Lauwerys R, Sibille Y. Clara cell protein in serum and bronchoalveolar lavage. Eur Respir J 1992; 5: 1231-1238. 